\title{
Toxicity of Neem Leaf Extracts (Azadirachta indica A. Juss) on Some Haematological, Ionoregulatory, Biochemical and Enzymological Parameters of Indian Major Carp, Cirrhinus mrigala
}

\author{
M. Saravanan ${ }^{1}$, M. Ramesh*1, A. Malarvizhi ${ }^{1}$ and \\ R. Petkam ${ }^{2}$ \\ ${ }^{1}$ Unit of Toxicology, Department of Zoology, School of Life Sciences, \\ Bharathiar University, Coimbatore-641 046, Tamil Nadu, India. \\ ${ }^{2}$ Department of Fisheries, Faculty of Agriculture, Khon Kaen University, \\ Khon Kaen-40002, Thailand.
}

Date Received: 25-06-2011 Date Accepted: 10-09-2011

\begin{abstract}
In the present study, the median lethal concentration (LC 50) of neem leaf extract to Cirrhinus mrigala for $24 \mathrm{~h}$ was found to be $1.035 \mathrm{~g} \mathrm{l}^{-1}$. During the study period, the haematological parameters including $\mathrm{Hb}, \mathrm{Hct}, \mathrm{RBC}, \mathrm{MCV}, \mathrm{MCH}$ and $\mathrm{MCHC}$ levels were significantly decreased in neem leaf extract exposed fish when compared to the control fish whereas WBC count was increased. Similarly, plasma $\mathrm{Na}^{+}$and $\mathrm{Cl}^{-}$levels were significantly lower and $\mathrm{K}^{+}$level were significantly higher when compared to the control. In biochemical study, elevated plasma glucose and induced protein levels were noticed. The enzymes, glutamate oxaloacetate transaminase (GOT) and glutamate pyruvate transaminase (GPT) activities were increased significantly in gill, liver and muscle of treated fish compared to that of their control groups. The results of the present investigation suggest that neem leaf extracts affects the hematological, ionoregulatory, biochemical and enzymological parameters of fish and alterations of these parameters can be useful in environmental biomonitoring of neem based products in freshwater environment.
\end{abstract}

Keywords: Azadirachta indica, Acute toxicity, Cirrhinus mrigala, Haematology, Ion regulation, Biochemical and Enzymological parameters.

*Correspondence: E-mail-mathanramesh@yahoo.com,

Tel-+91-422-2428394, Fax-+91-422-2422387,

ISSN 2235-9370 Print/ ISSN 2235-9362 Online @2011 University of Sri Jayewardenepura

14 


\section{Introduction}

Many studies illustrated that neem (Azadirachta indica) extract has widely used in controlling of insect pests (Kreutzweiser et al., 2004). The water soluble part of neem based extracts possess hypoglycemic, hypolipidemic, anti-inflammatory, hepatoprotective, antifertility activities and used as a chemo preventive agent in different parts of the world (Chattopadhyay et al.,, 1993). Recently the use of medicinal plants particularly neem based products as alternatives of synthetic pesticides has gained importance and extensively used in aquaculture to control fish predators and pathogens (Martinez, 2002; Tiwari and Singh, 2003; Winkaler et al., 2007). The widely used neem based biopesticides directly enter into the various water resources such as streams, river, and lakes, and may affect the non-target organisms (Schröder, 1992). Fish is the most susceptible to water contamination than any other aquatic organism. Recently, biomarkers are widely used as early diagnostic tools for environmental quality assessment in polluted water bodies (Cajaraville et al., 2000).

Measurement of haematological parameters are important in diagnosing the structural and functional status of animals exposed to the toxicant because blood parameters are highly sensitive to environmental or physiological changes and health conditions (Talas et al., 2009; Suvetha et al., 2010). Similarly, monitoring of fish plasma electrolyte levels may allow partial assessment of the eco-physiological status of fish and to detect possible aquatic stress (Suvetha et al., 2010). Measurement of specific ion concentrations $\left(\mathrm{Na}^{+}, \mathrm{K}^{+}\right.$and $\left.\mathrm{Cl}^{-}\right)$has potential as sensitive biomarkers of environmental chemical exposure. Biochemical biomarkers are commonly used for detecting or diagnosing physiological changes in fish exposed to various toxic substances. Among the biochemical biomarkers, plasma glucose and protein levels have long been used as indicators of stress in fish (Ramesh, 2001). Enzyme activities have also been used as sensitive indicators of stress in fish exposed to diverse groups of water pollutants and also to predict the possible levels of threat to life. Measurement of plasma GOT and GPT enzyme activity in toxicant exposed fish serve as a valuable indicator of physiological changes or stress condition of fish (Knox and Greengard, 1965; Remyla et al., 2008).

Many authors have reported the impact of neem based products on the physiology of aquatic organisms particularly fish. Neem leaf extract alters the haematological and biochemical parameters in Prochilodus lineatus at acute and sublethal concentrations (Winkaler et al., 2007). Extract of the neem bark had been reported to cause respiratory problems in Tilapia zilli (Omoregie and Okpanachi, 1997) and crude extract of neem delayed the growth of cichlid fish (Omoregie and Okpanachi, 1992). In India, the usage of neem products has been increased rapidly such as soil fertilizer, insect repellent and an insecticide, molluscicidal, sterilant, antifeedant, antiattractant or repellent and ecdysone inhibitor (van der Nat, 1991; Sharma and Dhiman, 1993; Warbric et al., 1993; Biswas et al., 2002), based on their frequent availability, biodegradability and safety for human and the environment (Tiwari and Singh, 2004). However, the impact of neem based products with reference to an Indian major carp C. mrigala is very limited. Cirrhinus mrigala is an important Indian major carp and widely cultivated in different parts of India for edible and economic importance. Therefore, in this study we aimed to evaluate the toxic effects of aqueous leaf extract of $A$. indica on certain haematological, ionoregulatory and biochemical parameters of $C$. mrigala. The present study is also aimed at establishing the safe limits of aqueous extracts of neem on water quality. 


\section{Materials and methods}

\subsection{Experimental animal and water}

Fingerlings of $C$. mrigala in the weight range of $8.0 \pm 0.5 \mathrm{~g}$ and body length of $8.0 \pm 1 \mathrm{~cm}$ were obtained from Tamil Nadu Fisheries Development Corporation Limited, Aliyar Fish Farm, Aliyar, Tamil Nadu, India. They were safely brought to the laboratory and stocked in a large cement tank (1,000 litre capacity). The tank was disinfected with potassium permanganate and washed thoroughly prior to introduction of fish. During the acclimatization period (20 days) fish were fed ad libitum with rice bran and groundnut oil cake in the form of dough once daily. One-third of water in the tank was renewed daily and feeding was withheld $24 \mathrm{~h}$ before the commencement of the experiment. In this study, tap water free from chlorine was used and the water had the following physico-chemical characteristics given in Table 1(APHA, 1998). Before the start of experiment, fish were randomly divided into two groups which were housed in $200 l$ glass aquaria with tap water which was continuously aerated.

Table 1. Physico-chemical features of water used for the experiment.

\begin{tabular}{ll}
\hline Physico-chemical parameters & Values \\
\hline Temperature & $27.4 \pm 1.2^{\circ} \mathrm{C}$ \\
$\mathrm{pH}$ & $7.2 \pm 0.09$ \\
Dissolved oxygen & $6.4 \pm 0.04 \mathrm{~g} \mathrm{l}^{-1}$ \\
Total alkalinity & $18.6 \pm 8.0 \mathrm{~g} \mathrm{l}^{-1}$ \\
Total hardness & $18.4 \pm 0.5 \mathrm{~g} \mathrm{l}^{-1}$ \\
Salinity & $0.4 \pm 0.02 \% \circ$ \\
Calcium & $4.3 \pm 0.3 \mathrm{~g} \mathrm{l}^{-1}$ \\
Magnesium & $2.6 \pm 0.6 \mathrm{~g} \mathrm{l}^{-1}$ \\
\hline
\end{tabular}

Values are mean \pm S.E. of five individual observations

\subsection{Preparation of aqueous neem leaf extracts}

The leaves of neem (A. indica) were collected in and around Bharathiar University campus, dried and chopped finely. The leaves were soaked in the ratio of $25 \mathrm{~g}$ of dried leaves per liter of water for 24 hours at room temperature (Cruz et al., 2004). Then the mixture was filtered and the extract $\left(25 \mathrm{~g} \mathrm{l}^{-1}\right.$ of stock solution) was used immediately for the experiment at different dilutions.

\subsection{Determination of $24 h L C_{50}$ value of neem leaf extracts}

A static acute toxicity $(24 \mathrm{~h})$ test was conducted to determine the $\mathrm{LC}_{50}$ value of neem leaf extract toxicity under laboratory condition. Different concentrations of the neem leaf extract at $0.25,0.50,0.75$, $1.0,1.25,1.50 \mathrm{ppm}$ were prepared from the stock solution. For each concentration 10 fish randomly selected from the stock were introduced and kept in separate glass tanks $(120 \mathrm{~cm} \mathrm{X} 80 \mathrm{~cm} \mathrm{X} 40 \mathrm{~cm})$. 
Three replicates were maintained for each concentration. A concurrent control was also maintained in three different tanks throughout the experimental period under identical conditions. The mortality/survival of fish was recorded after $24 \mathrm{~h}$. The dead fish were removed from the tanks immediately. Feeding was withheld during the bioassay experiment. The concentration at which $50 \%$ mortality of fish occurred after $24 \mathrm{~h}$ was taken as the medium lethal concentration $\left(\mathrm{LC}_{50}\right)$ for $24 \mathrm{~h}$, which was $1.035 \mathrm{ppm}$. The $\mathrm{LC}_{50}$ concentration for $24 \mathrm{~h}$ was calculated by the probit analysis method (Finney, 1978). Homogenicity of the population used in the present investigation was tested using chi-square test.

\subsection{Acute toxicity studies}

At the end of $24 \mathrm{~h}$ period, fish from the control and experimental aquaria were taken for the analysis of haematological indices (haemoglobin, haematocrit, erythrocyte, leucocyte, mean cellular volume, mean cellular haemoglobin and mean cellular haemoglobin concentrations), plasma electrolytes $\left(\mathrm{Na}^{+}\right.$, $\mathrm{K}^{+}$and $\mathrm{Cl}^{\prime}$ ), biochemical parameters (plasma glucose and protein) and enzymological parameters (GOT and GPT in gill, liver and muscle).

\subsection{Blood collection and haematological studies}

Blood was drawn from cardiac region by cardiac puncture using plastic disposable syringe fitted with 26-gauge needle which was already moistened with heparin and expelled into separate heparinised plastic vials immediately on ice. Blood samples were collected for haematological studies. Haematocrit was estimated by microhaematocrit (Capillary) method by Nelson and Morris (1989) using a microhaematocrit reader. Erythrocytes and leucocytes were counted by the method of Rusia and Sood (1992) using haemocytometer and haemoglobin content of the blood was estimated by Cyanmethaemoglobin method (Drabkin, 1946).

Erythrocyte indices of fish viz., mean cell volume (MCV), mean cell haemoglobin (MCH) and mean cell haemoglobin concentration (MCHC) were calculated from $\mathrm{RBC}, \mathrm{Ht}$, and $\mathrm{Hb}$ according to Lee et al. (1998) as follows:

$\mathrm{MCV}\left[\mu \mathrm{m}^{3} \mathrm{cell}^{-1}\right]=\mathrm{Ht}[\mathrm{v} / \mathrm{v}$ ratio $] \mathrm{X} 1000 / \mathrm{RBC}\left[10^{6} \mathrm{cell}^{-1} \mathrm{l}^{-1}\right]$,

$\mathrm{MCH}\left[\mathrm{pg}\right.$ cell $\left.^{-1}\right]=\mathrm{Hb}\left[\mathrm{gdl}^{-1}\right] \mathrm{X10} / \mathrm{RBC}\left[10^{6}\right.$ cell $\left.\mu \mathrm{l}^{-1}\right]$, and

$\mathrm{MCHC}\left[\mathrm{gdl}^{-1}\right]=\mathrm{Hb}\left[\mathrm{gdl}^{-1}\right] / \mathrm{Ht}[\mathrm{v} / \mathrm{v}$ ratio $]$.

\subsection{Estimation of Plasma electrolytes}

Plasma (blood) was prepared by centrifuging the blood sample at 10,000 rpm for 15 minutes. The sample was then used to measure plasma ionic $\left(\mathrm{Na}^{+}, \mathrm{K}^{+}\right.$and $\left.\mathrm{Cl}^{-}\right)$levels. Sodium and potassium were estimated by the method of Maruna (1958), while chloride was estimated by modified method of Tietz (1990) and Young et al. (1975).

\subsection{Biochemical parameters}

Plasma glucose was estimated by $O$-toluidine method (Cooper and McDanial, 1970) and plasma protein by the method of Lowry et al. (1951). 


\subsection{Enzymological parameters}

The gills, liver and muscles were isolated from the control and treated fish and $100 \mathrm{mg}$ of each tissue were weighed and homogenized with $2.5 \mathrm{ml}$ of $0.25 \mathrm{M}$ sucrose solution in ice cold condition (Hogeboom et al., 1948). The homogenates were centrifuged for 20 minutes at $6000 \mathrm{rpm}$ and clear supernatant fluid was taken for the estimation of GOT and GPT activities. GOT and GPT activities were estimated by 2, 4-DNPH method (Reitmen and Franckel, 1957).

\subsection{Statistical analysis}

The data were statistically analysed at $p<0.05$. Student's $t$-test was used to test their significance.

\section{Results}

$\mathrm{LC}_{50}(24 \mathrm{~h})$ value of $A$. indica leaf extract to $C$. mrigala was found to be $1.035 \mathrm{~g} \mathrm{l}^{-1}$. During acute treatment, the fingerlings of $C$. mrigala exhibited behavioural responses such as profuse secretion of mucus, hypersensitivity, erratic swimming, loss of reflex, air gulping etc. The Chi-square test on the toxicity data indicated that the fish population used for the experiments was homogeneous.

\subsection{Haematological indices}

Table. 2: Changes in $\mathrm{Hb}, \mathrm{Hct}, \mathrm{RBC}, \mathrm{WBC}, \mathrm{MCV}, \mathrm{MCH}$ and $\mathrm{MCHC}$ level of a freshwater fish Cirrhinus mrigala treated with acute concentration of neem leaf extracts $\left(1.035 \mathrm{~g} \mathrm{l}^{-1} ; 24 \mathrm{~h}\right)$.

\begin{tabular}{lllc}
\hline Parameters & Control & Experiment & Percent change \\
\hline $\mathrm{Hb}(\mathrm{g} / \mathrm{dl})$ & $4.3916 \pm 0.024$ & $1.4181 \pm 0.081^{*}$ & -67.70 \\
$\mathrm{Hct}(\%)$ & $13.1 \pm 0.044$ & $4.97 \pm 0.287^{*}$ & -62.29 \\
$\mathrm{RBC}($ million/cu.mm) & $0.5660 \pm 0.010$ & $0.4640 \pm 0.012^{*}$ & -18.02 \\
$\mathrm{WBC}(1000 /$ cu.mm) & $13.94 \pm 0.282$ & $21.93 \pm 0.551^{*}$ & +57.31 \\
$\mathrm{MCV}$ (cubic micra) & $235.15 \pm 4.926$ & $106.32 \pm 4.967^{*}$ & -54.78 \\
$\mathrm{MCH}$ (picograms) & $77.69 \pm 1.456$ & $30.50 \pm 1.314^{*}$ & -60.74 \\
MCHC (g/ dl) & $33.52 \pm 0.109$ & $28.71 \pm 0.444^{*}$ & -14.34 \\
\hline
\end{tabular}

Values are mean \pm S.E. of five individual observation, $(+)$ denotes percent increase over control, $(-)$ denotes percent decrease over control, * Values are significant at $p<0.05$, (based on t test).

The values of various haematological parameters such as $\mathrm{Hb}, \mathrm{Hct}, \mathrm{RBC}, \mathrm{WBC}, \mathrm{MCV}, \mathrm{MCH}$ and $\mathrm{MCHC}$ of $C$. mrigala exposed to $A$. indica aqueous leaf extract toxicity for $24 \mathrm{~h}$ registered a significant $(p<0.05)$ decrease from that of their control group (Table 2).

\subsection{Plasma ionic levels}

Plasma $\mathrm{Na}^{+}$level was significantly $(p<0.05)$ lower $(-33.05 \%)$ in the leaf extract treated fish than that of the control group at the end of $24 \mathrm{~h}$ (Table 3 ). Similarly, plasma $\mathrm{Cl}^{-}$level was also decreased significantly 
$(p<0.05)$ in the treated fish when compared to control group (Table 3). However, plasma $\mathrm{K}^{+}$level was significantly $(p<0.05)$ higher in treated fish (Table 3$)$.

Table. 3: Alterations in plasma sodium, potassium and chloride levels of control and neem leaf extracts treated fish $\left(1.035 \mathrm{~g} \mathrm{l}^{-1} ; 24 \mathrm{~h}\right)$. Values are means \pm S.E. of five individual observations; Significant $(p<0.05)$.

\begin{tabular}{lllc}
\hline Parameters & Control & Experiment & Percent change \\
\hline Sodium $(\mathrm{mmol} / \mathrm{l})$ & $151.80 \pm 1.104$ & $101.62 \pm 2.032^{*}$ & -33.05 \\
Potassium $(\mathrm{mmol} / \mathrm{l})$ & $7.6545 \pm 0.210$ & $11.6199 \pm 0.030^{*}$ & +51.80 \\
Chloride $(\mathrm{mEq} / \mathrm{l})$ & $119.142 \pm 3.008$ & $48.127 \pm 4.668^{*}$ & -59.60 \\
\hline
\end{tabular}

Values are mean \pm S.E. of five individual observation, (+) denotes percent increase over control, (-) denotes percent decrease over control, *Values are significant at $p<0.05$, (based on t test).

\subsection{Biochemical parameters}

Table. 4: Changes in plasma glucose and protein content of control and neem leaf extracts treated fish $\left(1.035 \mathrm{~g} \mathrm{l}^{-1} ; 24 \mathrm{~h}\right)$. Values are means \pm S.E. of five individual observations; Significant $(p<0.05)$.

\begin{tabular}{lllc}
\hline Parameters & Control & Experiment & Percent change \\
\hline $\begin{array}{l}\text { Plasma glucose } \\
(\mathrm{mg} / 100 \mathrm{ml})\end{array}$ & $89.72 \pm 3.215$ & $143.61 \pm 1.967^{*}$ & +60.06 \\
Plasma protein $(\mu \mathrm{g} / \mathrm{ml})$ & $3.1751 \pm 0.124$ & $2.5590 \pm 0.085^{*}$ & -19.40 \\
\hline
\end{tabular}

Values are mean \pm S.E. of five individual observation, (+) denotes percent increase over control, (-) denotes percent decrease over control, * Values are significant at $p<0.05$, (based on $t$ test).

In biochemical parameters, plasma glucose was increased in treated fish $(+60.06 \%)$ when compared to control group (Table 4). On the contrary, plasma protein level decreased upto $-19.40 \%$ (Table 4).

\subsection{Enzymological parameters}

Tables. 5: Alterations of GOT activity in the gill, liver and muscle of a freshwater fish Cirrhinus mrigala treated with acute concentration of neem leaf extracts $\left(1.035 \mathrm{~g} \mathrm{l}^{-1} ; 24 \mathrm{~h}\right)$. Values are means \pm S.E. of five individual observations; Significant $(p<0.05)$.

\begin{tabular}{llll}
\hline GOT activity (IU/L) Control & Experiment & Percent change & \\
\hline Gill & $44.6 \pm 0.7483$ & $107.4 \pm 8.134^{*}$ & +140.80 \\
Liver & $56.0 \pm 1.5166$ & $65.6 \pm 1.662^{*}$ & +17.14 \\
Muscle & $54.0 \pm 0.7071$ & $97.0 \pm 2.236^{*}$ & +79.62 \\
\hline
\end{tabular}

Values are mean \pm S.E. of five individual observation, $(+)$ denotes percent increase over control, * Values are significant at $p<0.05$, (based on t test). 
In this study, GOT and GPT activities were significantly $(p<0.05)$ higher in gill, liver and muscle of fish exposed to aqueous leaf extract of $A$. indica than that of the control group (Tables 5-6).

Tables. 6: Alterations of GPT activity in the gill, liver and muscle of a freshwater fish Cirrhinus mrigala treated with acute concentration of neem leaf extracts $\left(1.035 \mathrm{~g} \mathrm{l}^{-1} ; 24 \mathrm{~h}\right)$. Values are means \pm S.E. of five individual observations; Significant $(p<0.05)$.

\begin{tabular}{llll}
\hline GPT activity (IU/L) & Control & Experiment & Percent change \\
\hline Gill & $45.8 \pm 1.2806$ & $73.0 \pm 4.427^{*}$ & +59.30 \\
Liver & $51.8 \pm 2.6533$ & $66.2 \pm 4.030^{*}$ & +27.79 \\
Muscle & $57.6 \pm 0.9273$ & $96.0 \pm 5.805^{*}$ & +66.66 \\
\hline
\end{tabular}

Values are mean \pm S.E. of five individual observation, $(+)$ denotes percent increase over control, * Values are significant at $p<0.05$, (based on t tes

\section{Discussion}

The various types of stressors in aquatic ecosystems and aquaculture practices have been shown to induce some changes in the physiological variables of fish (Martinez and Souza, 2002). In this study, we found that the median lethal concentration $\left(\mathrm{LC}_{50}\right.$ for $\left.24 \mathrm{~h}\right)$ of aqueous extract of neem leaf to the fingerlings of $C$. mrigala was $1.035 \mathrm{~g} \mathrm{l}^{-1}$ which indicates that aqueous extract of neem leaf is toxic to fish. The toxicity of neem extract varies depending on the fish species. The $24 \mathrm{~h} \mathrm{LC}_{50}$ of neem leaves extract for P. lineatus was $4.8 \mathrm{~g} \mathrm{l}^{-1}$ (Cruz et al., 2004), $96 \mathrm{~h} \mathrm{LC}_{50}$ of neem leaf extract for $96 \mathrm{~h}$ in Channa punctatus was $3.00 \mathrm{ppm}$ (Farah et al., 2006), and 24 and $96 \mathrm{~h} \mathrm{LC}_{50}$ of Nerium indicum leaf extracts for Channa punctatus was $17.34 \mathrm{mg} \mathrm{l}^{-1}$ and $13.58 \mathrm{mg} \mathrm{l}^{-1}$ respectively (Tiwari and Singh, 2003). According to Singh and Singh, (2002) the $24 \mathrm{~h} \mathrm{LC}_{50}$ values of stem bark extracts of Euphorbia royleana, Jatropha gossypifolia, $N$. indicum and Thevetia peruviana to C. punctatus was $0.050 \mathrm{~g} \mathrm{l}^{-1}, 4.61 \mathrm{~g} \mathrm{l}^{-1}, 0.097 \mathrm{~g} \mathrm{l}^{-1}$, and $4.05 \mathrm{~g} \mathrm{l}^{-1}$, respectively.

Behavioural toxicology is a tool for hazard assessment of water pollution. In the present investigation, during acute treatment, behavioural responses such as erratic movements, increasing mucous secretion, body imbalance, surface floating, restlessness and loss of equilibrium were observed. Similar observations were also observed by Tiwari and Singh (2004) in fish C. punctatus exposed to stem bark extract of neem and in Lepidocephalichthys guntea exposed to nimbecidine and neem gold (Mondal et al., 2007). Alterations in physiological and biochemical parameters of toxicant treated fish have recently emerged as vital indices for water quality assessment in the field of environmental toxicology (Suvetha et al., 2010). Moreover, haematological parameters are closely associated to the response of the fish to the environment (Tiwari and Sing, 2006).

Changes in the erythrocyte profile of toxicant treated fish indicate a compensation of oxygen deficit in the body due to gill damage (Drastichova et al., 2004). Reduction in RBC may be caused either by the inhibition of erythropoiesis or by the destruction of red cells (Hota, 1995) and destruction of hematopoietic 
tissue in kidney and spleen (Iwama et al., 1976). Svobodova et al. (1991) reported that reduced haemoglobin content and haematocrit in toxicant exposed fish may be due to disruption of haemopoietic processes and accelerated disintegration of erythrocyte cell membranes. In Ictalurus punctatus the decreased $\mathrm{Hb}$ content was due to the swelling of RBC, as well as to poor mobilization of $\mathrm{Hb}$ from the spleen and other haemopoietic organs (Scott and Rogers, 1981). In this study, the significant decrease in RBC count, haemoglobin content and haematocrit values of fish C. mrigala treated with aqueous extract of neem leaf $\mathrm{h}$ might have resulted from destruction of RBCs due to erythroblastosis leading to anemia.

Zhang et al. (2007) investigated a significant decrease in haematological indices including MCH, $\mathrm{MCHC}$ and MCV in Carassius auratus to intraperitoneal injection of extracted microcystins and suggested that the decrease in haematological indices may be a compensation for impaired oxygen uptake due to gill damage. Similar alterations of MCH, MCV and MCHC values of C. mrigala were noted in this study which may be due to swelling of red blood cells or release of young erythrocytes containing less hemoglobin into the blood circulation (Sobecka, 2001). WBCs are involved in the regulation of immunological function and their numbers increase as a protective response in fish to stress (Nussey et al., 2002; Pimpao et al., 2007). Winkaler et al. (2007) reported that WBC levels in neem leaf extract treated fish increased from the control level, as a consequence of gill damage. Increased total leucocyte cell count in monosex Nile tilapia, Oreochromis niloticus exposed to acute concentration of deltamethrin may be due to stimulated lymphopoiesis and enhanced release of lymphocytes from lymphomyeloid tissue (El-Sayed et al., 2007). In the present study, the significant increase in the number of WBC indicates the stress condition of the fish caused by neem leaf extract which might have produced hypoxia and gill damage.

Freshwater animals compensate their renal and surface loss of ions, mainly sodium and chloride by absorbing these ions from the external medium and maintain their normal physiological process and body fluid homeostasis with the help of ion/osmoregulatory processes (Hwang and Lee, 2007; Suvetha et al., 2010). The effects of toxicants on osmotic and ionic regulation have been calculated by means of measuring concentrations of individual ions and total osmolarity in fish plasma (Barcarolli and Martinez, 2004). Mathan et al. (2010) reported that alterations in ionic balance may be due to due to stress effects on the ionoregulatory organs. McCarty and Houstan (1976) reported that the decrease in plasma electrolyte levels tend to be associated with increases in tissue concentration, particularly sodium and chloride. Wood et al. (1996) proposed that the net loss of $\mathrm{Na}^{+}$and $\mathrm{Cl}^{-}$at the gills cause a steady decline in plasma concentration of these ions. Further, an apparent decrease of blood chloride concentrations in fish might be due to reduced activity of carbonic anhydrase or interference of cortisol (Thomas and Murthy, 1976). Decreased level of plasma potassium indicates the inhibition of the $\mathrm{Na}^{+} / \mathrm{K}^{+}$ATPase activity (Suvetha $e t$ al., 2010). Further, osmoregulatory failure may also be a reason for decreased levels of major plasma electrolytes.

In the present investigation, the decreased level of plasma electrolytes levels might have resulted from the toxicity of neem leaf extract which may have accumulated on the gill surface; either had damaged or altered the membrane permeability leading to lesser intake of electrolytes into the body or efflux of the same to the exterior. Freshwater animals compensate their renal and surface loss of ions, mainly sodium and chloride, by absorbing these ions from the external medium through specialized 
surface structures (gills in fish). Gills of freshwater fish contain the machinery for the active transport of electrolytes and play an important role in the transport of respiratory gases and regulating of osmotic and ionic balance. Toxic substances may cause damage to gill tissues, thereby reducing the oxygen consumption and disturbing the osmoregulatory function of aquatic organisms. On the other hand, a significant increase in plasma potassium level might be due to this fact that this ion was transported from other tissues to blood or their consequent reduction in the tissues due to imbalances in the osmoregulation process.

Biochemical parameters can be helpful to identify the target organs of toxic effects and also the general health condition of animals. They also provide early warning of potentially harmful changes in stressed organisms (Ferreira et al., 2007). The increase in blood glucose level might be resulted from an increase in plasma catecholamine and corticosteroid hormones (Pickering, 1981). In the present study also hyperglycemic condition was observed which may be due to coping up the stress caused by aqueous neem leaf extract. Martinez et al. (2004) reported that fish under stress conditions may mobilize protein to meet energy requirements and to sustain increased physiological activity. The decrease in protein level observed in the freshwater fish C. punctatus exposed to latices of E. royleana and J. gossypifolia may be attributed to the destruction or necrosis of cells and consequent impairment in protein synthesis (Singh and Singh, 2002). A similar mechanism may be operated in the present study also.

Manavalaramanujam and Ramesh (1996) reported that the elevation of GOT and GPT activity in pesticide treated fish indicates the increased energy demands under pesticide stress. Increased GOT and GPT indicates hepatic tissue damage (Agrahari et al., 2007). In the present study, the activity of both GPT and GOT was increased in the gill, liver and muscle tissue of $C$. mrigala indicating damage of the organs due to accumulation of aqueous extract of neem leaf or increased metabolism as the organism tries to mitigate the induced stress. Moreover, detoxification process may not be sufficiently effective to prevent the action of neem leaf extract on the system resulting an increase in GOT and GPT activities in gill, liver and muscle of fish.

\section{Conclusion}

In India, the health hazard of $A$. indica plant leaf extract to aquatic organisms particularly in $C$. mrigala has not been studied in detail. The findings of the present study showed that neem leaf extracts $\left(1.035 \mathrm{~g} \mathrm{l}^{-1}\right)$ affects the hematological, ionoregulatory, biochemical and enzymological parameters of $C$. mrigala even during a short-term exposure (24h). These parameters could be effectively used as potential biomarkers of neem leaf extracts toxicity to the freshwater fish in the field of environmental biomonitoring. The observed $\mathrm{LC}_{50}$ value and altered parameters may help to establish the safer level of the aqueous extracts of $A$. indica to the aquatic environment and aquaculture farms. Furthermore, chronic studies on these parameters need to be further investigated in future.

\section{References}

Agrahari, S., Kashev, C., Pandey, Gopal, K., 2007. Biochemical alteration induced by monocrotophos in the blood plasma of fish, Channa punctatus (Bloch). Pestic. Biochem. Physiol. 268-272. 
APHA., 1998. Standard methods for the examination of water and wastewater, twentieth ed. American Public Health Association, Washington, DC.

Barcarolli, IF., Martinez, C.B.R., 2004. Effects of aluminium in acidic water on hematological and physiological parameters of the Neotropical fish Leporinus macrocephalus (Anostomidae). Bull. Environ. Contam. Toxicol. 72, 639-646.

Biswas, K., Chattopadhyay, I., Banerjee, R.K., Bandyopadhyay, U., 2002. Biological activities and medicinal properties of neem (Azadirachta indica). Cur. Sci. 82, 1336-1345.

Cajaraville, MP., Bebianno, M.J., Blasco, J., Porte, C., Sarasquete, C., Viarengo, A., 2000. The use of biomarkers to assess the impact of pollution in coastal environments of the Iberian Peninsula: a practical approach. Sci. Total. Environ. 247, 295-311.

Chattopadhyay, R.N., Maitra, S.K., Chattopadhyay, R.R., 1993. Possible mechanism of antihyperglycemic effect of Azadirachta indica leaf extract: Part I. Fitoterapia. 64, 332-335.

Cooper, G.R., McDaniel, V., 1970. The determination of glucose by the $O$-toluidine method. Standard Method for Clinical Chemistry, 159.

Cruz, C., Machado-Neto, J.G., Menezes, M.L., 2004. Toxicidade aguda do inseticida Paration metílico e do biopesticida azadiractina de folhas de neem (Azadirachta indica) para alevino e juvenil de pacu (Piaractus mesopotamicus). Pesticidas: Revista de Ecotoxicologia e Meio Ambiente. 14, 92-102.

Drastichova, J., Svobodova, Z., Luskova, V., Machova, J., 2004. Effect of cadmium on hematological indices off common carp Cyprinus carpio (L.). Bull. Environ. Contam. Toxicol. 72, 725-732.

El-Sayed, Y.S., Saad, T.T., El-Bahr, S.M., 2007. Acute intoxication of deltamethrin in monosex Nile tilapia, Oreochromis niloticus with special reference to the clinical, biochemical and haematological effects. Environ. Toxicol. Pharmacol. 24, 212-217.

Farah, A.M., Bushra, A., Ahmad, W., 2006. Antimutagenic effect of neem leaves extract in freshwater fish, Channa punctatus evaluated by cytogenetic tests. Sci. Total Environ. 364, 200-214.

Ferreira, J.G., Hawkins, A.J.S., Bricker, S.B., 2007. Management of productivity, environmental effects and profitability of shellfish aquaculture-the Farm Aquaculture Resource Management (FARM) model. Aquaculure. 264, 160-174.

Finney, D.J., 1978. In: Statistical methods in biological assay, third ed. Griffin Press., London, U.K, 508.

Hogeboom, G.H., Schneider, W.C., Pallade, G.E., 1948. Cytochemical studies of mammalian tissues I. Isolation of intact mitochondria from rat liver; some biochemical properties of mitochondria and submicroscopic particulate material. J. Biol. Chem. 72, 619-635.

Hota, S., 1995. Toxic effect of arsenic on haemato biochemical abnormalities in Channa punctatus (Bloch). J. Ecotoxicol. Environ. Monit. 5, 249255.

Hwang, P.P., Lee, T.H., 2007. New insights into fish ion regulation and mitochondrion-rich cells. Comp. Biochem. Physiol. 48, 479-497.

Iwama, G.K., Greer, G.L., Larkin, P.A., 1976. Changes in some hematological characteristics of coho salmon (Oncorhynchus kisutch) in response to acute exposure of dehydroabietic acid (DHAA) at different exercise levels. J. Fish Res. Board Canada. 33, 285-289.

Knox, W.E., Greengard, O., 1965. In: An introduction to enzyme physiology, Weber, G. (Edn.), Advances in enzyme regulation. Pergamon Press., New York, 247-248. 
Kreutzweiser, D.P., Back, R.C., Sutton, T.M., Pangle, K.L., Thompson, D.G., 2004. Aquatic mesocosm assessments of a neem (azadirachtin) insecticide at environmentally realistic concentrations-2: Zooplankton community responses and recovery. Ecotoxicol. Environ. Safe. 59, 194-204.

Lee, R.G., Foerster, J., Jukens, J., Paraskevas, F., Greer, J.P., Rodgers, G.M., 1998. Wintrobe's-Clinical hematology, tenth en. Lippincott Williams and Wilkins., New York, USA.

Lowry, O.H., Rosenbrough, N.J., Farr, A.L., Randell, R.J., 1951. Protein measurement with foline phenol reagent. J. Biol. Chem. 193, 265-275.

Manvalaramanujam, R., Ramesh, M., 1996. Sublethal toxicity of phosalone on transaminases of a freshwater fish Labeo rohita. J. Ecol. Environ. Conserv. 2, 179-181.

Martinez, S.O., 2002. NIM-Azadirachta indica: natureza, usos múltiplose produção. Instituto Agronômico do Paraná (IAPAR), Londrina, PR.

Martinez, C.B.R., Nagae, M.Y., Zaia, C.T.B.V., Zaia, D.A.M., 2004. Morphological and physiological acute effects of lead in the Neotropical fish Prochilodus lineatus. Brazilian J. Biol. 64, 797-807.

Martinez, C.B.R., Souza, M.M., 2002. Acute effects of nitrite on ion regulation in two Neotropical fish species. Comp. Biochem. Physiol. A. 33, 151-160.

Maruna, R.F.L., 1958. Quantitative estimation of sodium $\left(\mathrm{Na}^{+}\right)$, potassium $\left(\mathrm{K}^{+}\right)$in human serum by colorimetric method. Clin. Chim. Acta. 2, 581-585.

Mathan, R., Senthil Kumar, K., Mahalashmi Priya., 2010. Alterations in plasma electrolyte levels of a freshwater fish. Cyprinus carpio exposed to acidic pH. Toxicol. Environ. Chem. 92, 149-157.

McCarty, L.S., Houston, A.H., 1976. Effects of exposure to sublethal levels of cadmium upon waterelectrolyte status in the gold fish, Carassius auratus. J. Fish Biol. 9, 11-19.

Mondal, D., Barat, S., Mukhopadhyay, M.K., 2007. Toxicity of neem pesticides on a fresh water loach, Lepidocephalichthys guntea (Hamilton Buchanan) of Darjeeling district in West Bengal. J. Environ. Biol. 28, 119-22.

Nelson, D.A., Morris, M.W., 1989. Basic methodology. Chap. 27. Hematology and coagulation, part IV, in: Clinical diagnosis and management by laboratory methods. Nelson, D.A., Henry, J.B. seventieth ed. Henry, J.B, W.B. Saunder Company., Philadelphia, U.S.A. 578-625.

Nussey, G., Van, Vuren, J.H.J., Du Preez, H.H., 2002. The effect of copper and zinc at neutral and acidic $\mathrm{pH}$ on the general hematology and osmoregulation of Oreochromis mossambicus. African J. Aquat. Sci. 27, 61-84.

Omoregie, E., Okpanachi, M.A., 1992. Growth of Tilapia zilli exposed to sublethal concentrations of crude extracts of Azadirachta indica. Acta Hydrobiol. 34, 281-286.

Omoregie, E., Okpanachi, M.A., 1997. Acute toxicity of water extracts of bark of the Neem plant, Azadirachta indica (Lodd) to the cichlid Tilapia zillii (Gervais). Acta Hydrobiol. 39, 47-51.

Pickering, A.D., 1981. Stress and compensation in teleostean fishes. Response to social and physical factors, in: Pickering, A.D. (Edn.), Stress and Fish, Academic press., New York/London, 295-322.

Pimpao, C.T., Zampronio, A.R., Silva de Assis, H.C., 2007. Effects of deltamethrin on hematological parameters and enzymatic activity in Ancistrus multispinis (Pisces, Teleostei). Pestic. Biochem. Physiol. 88:122-127.

Ramesh, M., 2001. Toxicity of copper sulphate on some haematological parameters of a freshwater teleost Cyprinus carpio var. communis. J. Indian Fish. Assoc. 28, 131-136. 
Reitman, S., Frankel, S., 1957. A colorimetric method for the determination of glutamic-oxaloacetic and glutamic-pyruvic transminases. American J. Clin. Pathol. 33:1-13.

Remyla, S.R., Ramesh, M., Sajwan, K.S., Senthil Kumar, K., 2008. Influence of zinc on cadmium induced haematological and biochemical responses in a freshwater teleost fish Catla catla. Fish. Physiol. Biochem. 34, 169-174

Rusia, V., Sood, S.K., 1992. Routine haematological tests, in: Medical laboratory technology, Kanai, L. Mukerjee, (Edn.), I. Fifth reprint, Tata McGraw Hill Publishing Company Limited., New Delhi, 252-258.

Schroder, P., 1992. Neem Azal/Neem Azal F in the aquatic environment. In: Kleeberg, H. (Ed.), Practice Oriented Results on Use and Production of Neem Ingredients. Proceedings of $1^{s t}$ Workshop, Druck and Graphic Giessen., Germany, 109-121.

Scott, A.L., Rogers, W.A. 1981. Hematological effects of prolonged sublethal hypoxia on channel catfish Ictalurus punctatus (Rafinesque). J. Fish. Biol. 18, 591-601.

Sharma, V.P., Dhiman, R.C., 1993. Neem oil as sand fly (Diptera: Psychodidae) repellant. J. American Mosq. Control Assoc. 9, 364-366.

Singh, D., Singh, A., 2002. Biochemical alteration in freshwater fish Channa punctatus due to latices of Euphorbia royleana and Jatropha gossypifolia. Environ. Toxicol. Pharmacol. 12, 129-1.

Sobecka, E., 2001. Changes in the iron leveling the organs and tissues of wells catfish, Silurus glanis L. caused by nickel. Acta Ichthyl. Et Pisc. 31, 127-143.

Suvetha, L., Ramesh, M., Saravanan, M., 2010. Influence of cypermethrin toxicity on ionic regulation and gill $\mathrm{Na}^{+} / \mathrm{K}^{+}$-ATPase activity of a freshwater teleost fish Cyprinus carpio. Environ. Toxicol. Pharmacol. 29, 44-49

Svobodova, D., Ravds, J., Palackova, L., 1991. Unified method of haematological examination of fish. Research Institute of Fish Culture and Hydrobiology, Vodamy, Czechoslovakia.

Talas, Z.S., Gulhan, M.F., 2009. Effects of various propolis concentrationson biochemical and hematological parameters of rainbow trout (Oncorhynchusmykiss). Ecotoxicol. Environ. Safe. 72, 1994-1998.

Thomas, P.C., Murthy, T.C., 1976. Studies on the impact of a ferric organic pesticide on certain fish enzymes. Indian J. Animal Sci. 46, 619-624.

Tietz, N.W., 1990. In: Clinical Guide to Laboratory Test, second edn. W.B. Saunders Co., Philadelphia, 118.

Tiwari, S., Singh, A., 2003. Control of common freshwater predatory fish, Channa punctatus, through Nerium indicum leaf extracts. Chemosphere. 53, 865-875.

Tiwari, S., Singh, A., 2004. Piscicidal and anti-acetyl cholinesterase activity of Euphorbia royleana stem bark extracts against freshwater common predatory fish Channa punctatus. Environ. Toxicol. Pharmocol. 18, 47-53.

Tiwari, S., Singh, A., 2006. Biochemical stress response in freshwater fish Channa punctatus induced by aqueous extracts of Euphorbia tirucalli plant. Chemosphere. 64, 36-42.

van der Nat, M.G., van Der Sluis, K.T.D., Labadie, R.P., 1991. Ethnophormocognostical survey of $A$. indica Juss (Maliaceae). J. Ethnopharmacol. 35, 1-24. 
Warbric, E.V., Barker, G.C., Rees, H.H., Howells, R.E., 1993. The effect of invertebrate hormones and potential hormone inhibitors on the third larval moult of the filarial nematode, Dicrofilaria immitis in vitro. Parasitol. 107, 459-463.

Winkaler, E.U., Santos, T.R.M., Machado-Neto, J.G., Martinez, C.B.R., 2007. Acute lethal and sublethal effects of neem leaf extract on the Neotropical freshwater fish Prochilodus lineatus. Comp. Biochem. Physiol. C. 145, 236-244.

Wood, C.M., Hogstrand, C., Glavez, F., Munger, R.S., 1996. The physiology of waterborne silver toxicity in freshwater rainbow trout, Oncorhynchus mykiss. The effects of silver thiosulfate. Aquat. Toxicol. $35,111-125$.

Young, D.S., Pestaner, L.C., Gibberman, V., 1975. Effects of drugs on clinical laboratory tests. Clin. Chem. 21, 1D-432D.

Zhang, X., Xie, P., Li, D., Shi, Z., 2007. Hematological and plasma biochemical responses of crucian carp (Carassius auratus) to intraperitoneal injection of extracted microcystins with the possible mechanisms of anemia. Toxicology. 49, 1150-1157. 